\title{
EFFECTS OF PLANT EXTRACTS AND DISINFECTANT HUVA-SAN TR 50 ON THE QUALITY OF CARROT (Daucus carota L.) SEEDS
}

\begin{abstract}
The aim of the study was to determine the effect of Aloe vera (L.) Burm.f. (Aloe) and Morinda citrifolia L. (Indian mulberry) plant extracts and disinfectant Huva-San TR 50 (hydrogen peroxide stabilized with silver ions) on carrot seed quality. The seeds of two carrot cultivars Amsterdam (sample I) and Berlikumer 2 (sample II), were soaked in solutions of Aloe and Indian mulberry extracts and Huva-San TR 50 at concentrations of $0.025 \%, 0.05 \%$ and $0.1 \%$ for 30 min. Untreated seeds and seeds soaked in distilled water for 30 min were used as controls. Seed germination was assessed after 7 and 14 days of incubation. The speed and uniformity of seed germination (vigour) were evaluated. Mycological analysis was performed using a deep-freeze blotter test. Sample I was characterized by lower germination at the first and the final counts than sample II and higher seed infestation with Alternaria radicina. Treating seeds of sample I with Morinda citrifolia plant extract at concentrations of 0.025 and $0.05 \%$ reduced their infestation with Alternaria alternata and A. radicina, increased germination at the first and the final counts, and did not affect seed vigour. The effects of Aloe extract and disinfectant Huva-San TR 50 on seed quality parameters varied depending on their concentration. Hence, further studies are necessary to establish the optimal conditions for carrot seed treatment.
\end{abstract}

Keywords: Aloe vera, Morinda citrifolia, hydrogen peroxide, seed germination and vigour, fungi

\section{Introduction}

The most severe fungal diseases of carrot (Daucus carota L.) are black rot of roots and leaf blight caused by seed-borne Alternaria radicina Meier, Drechsler et Eddy and Alternaria dauci (Kühn) Groves et Skolko, respectively. Moreover, carrot seeds are commonly and abundantly infested with Alternaria alternata (Fr.) Keissler, which may be potentially pathogenic to this plant [1]. Fungi from genus Alternaria are usually a reason of low carrot seed germination and poor seedling establishment [2]. Synthetic fungicides are commonly used to control seed-transmitted pathogens, but global need for more organic production, including discarding standard pesticides, has resulted in the search for novel, alternative methods of seed treatment.

Aloe vera (L.) Burm.f. (Aloe) and Morinda citrifolia L. (Indian mulberry), have been used traditionally in an alternative medicine due to proven antihelminthic, analgesic,

\footnotetext{
${ }^{1}$ Department of Entomology and Environmental Protection, Poznań University of Life Sciences, ul. J.H. Dąbrowskiego 159, 60-594 Poznań, Poland, +48 618466 336, email: romuald.gorski@ up.poznan.pl

${ }^{2}$ Department of Phytopathology, Seed Science and Technology, Poznań University of Life Sciences, ul. J.H. Dąbrowskiego 159, 60-594 Poznań, Poland, +48 618466382

${ }^{3}$ Department of Vegetable Crops, Poznań University of Life Sciences, ul. J.H. Dąbrowskiego 159, 60-594 Poznań, Poland, email: jolanta.lisiecka@up.poznan.pl

*Corresponding author: dorota.szopinska@up.poznan.pl
} 
antimicrobial, anti-tumour, anti-inflammatory and immunostimulant properties and potent antioxidant activity [3, 4].

Two components are obtained from fresh $A$. vera leaves: a bitter, yellow liquid fraction and a mucilaginous pulp from the parenchymatous tissue, commercially designated as a gel [5]. Both, leaf pulp and exudate, contain over 75 active ingredients, among others anthraquinones (aloe-emodin, aloetic-acid, anthranol, aloin A and B, isobarbaloin, emodin, and ester of cinnamic acid), known for their anti-microbial properties, as well as phenolic compounds and some enzymes, like glutathione peroxidase and superoxide dismutase, which may be responsible for anti-oxidant effect of this plant [6]. Antifungal properties of Aloe against seed-associated fungi has been frequently confirmed. It has been found that extracts of this plant may control growth of: Alternaria alternata, A. citri, A. tenuissima, Aspergillus clavatus, A. flavus, A. niger, Botrytis cinerea, B. gladiolorum, Cladosporium spp., Colletotrichum coccodes, C. gleosporioides, Drechslera havaiensis, Fusarium oxysporum, F. proliferatum, F. subglutinans, F. verticillioides, Heterosporium pruneti, Penicillium chrysogenum, $P$. digitatum, $P$. expansum, $P$. funiculosum, $P$. gladioli, P. oxalicum, Rhizoctonia solani and Rhizopus stolonifer [7-15]. Reports about activity of Aloe extracts against field fungi are less numerous than those related to storage fungi, and in vitro assays prevail over in vivo experiments.

Morinda citrifolia fruit extract contains many antibacterial and antifungal compounds, such as: scopoletin, anthraquinones, terpenes and polysaccharides (glucuronic acid, galactose, arabinose, rhamose, glycosides, trisaccharide fatty acid ester) [4]. The reports about antifungal properties of this extract are related mostly to human pathogens, such as: Aspergillus niger, A. fumigatus and Candida albicans [16-19]. Nevertheless, there are also some information about activity of Indian mulberry extract against plant associated fungi and bacteria. Under in vitro conditions the extract has been found antifungal against Alternaria alternata, Aspergillus flavus and A. niger, isolated from groundnut (Arachis hypogaea L.) fruits [20]. Morinda methanol extract inhibited the growth of Penicillium sp., Fusarium sp. and Rhizopus sp. colonies by $50 \%$ [17]. In vitro assay revealed antibacterial activity of Indian mulberry fruit and leaves extracts against two different isolates of Ralstonia solanacearum, the pathogenic bacterium causing bacterial wilt of solanaceous plants [21]. Moreover, Morinda leaf extract inhibited the growth of Colletotrichum acutatum colony on PDA medium [22].

Huva-San TR 50 is a disinfectant based on hydrogen peroxide $\left(\mathrm{H}_{2} \mathrm{O}_{2}\right)$, which is stabilized with silver ions. Substantial antibacterial and antifungal properties of $\mathrm{H}_{2} \mathrm{O}_{2}$ resulted from high oxidative reactivity of this compound [23-25]. It is traditionally used in medicine and food industry as disinfectant, however, there are many reports, that treating seeds with $\mathrm{H}_{2} \mathrm{O}_{2}$ may also effectively control seed-associated fungi, such as: A. alternata, A. dauci and A. radicina [26], Alternaria zinniae [27], Sclerospora graminicola [28], Fusarium spp. [27], Peronospora tabacina [29], Tilletia controversa and T. tritici [30]. Additionally, the results of numerous experiments revealed that $\mathrm{H}_{2} \mathrm{O}_{2}$ treatment may improve seed germination [31]. This beneficial effect has been observed for: barley (Hordeum vulgare L.) and wheat (Triticum aestivum L.) [30], carrot [26], eastern gamagrass (Tripsacum dactyloides L.) [32], eggplant (Solanum melongena L.) [33], maize (Zea mays L.) [34], muscadine (Vitis rotundifolia Michx.) [35], pea (Pisum sativum L.) [36], rice (Oryza sativa L) [37], watermelon (Citrullus lanatus (Thunb.) Mansf.) [38], and zinnia (Zinnia elegans Jacq.) [39]. Although, silver plays a role of $\mathrm{H}_{2} \mathrm{O}_{2}$ stabilizer in Huva-San TR 50 preparation, it is also itself characterized by strong antimicrobial 
properties, known from ancient times. For years the most common form of silver application was silver nitrate $\left(\mathrm{AgNO}_{3}\right)$, however nowadays, silver nanoparticles are receiving increasing attention in the field of agriculture [40-42]. It has been proved that they may effectively inhibit growth of several fungi, such as: Aspergillus spp., Penicillium sp. and Rhizopus sp., but, with a growing concentration they may also negatively affect seed germination [42-44].

The effectiveness of pure $\mathrm{H}_{2} \mathrm{O}_{2}$ against pathogenic Alternaria spp. associated with carrot seed, as well as its beneficial influence on seed germination, have been proven before, however, there is no information how $\mathrm{H}_{2} \mathrm{O}_{2}$ stabilized with silver ions may affect carrot seed quality. Moreover, despite of numerous reports about antifungal properties of Aloe and Indian mulberry extracts, their ability to control seed-borne carrot pathogens has not been tested yet. Therefore, the aim of this experiment was to determine the effect of disinfectant Huva-San TR 50, as well as A. vera and $M$. citrifolia plant extracts on germination, vigour and health of carrot seeds.

\section{Material and methods}

\section{Material}

Two standard samples of carrot seeds, cv. Amsterdam (sample I) and cv. Berlikumer 2 (sample II), obtained from Torseed S.A., were used in the experiment. Aloe vera (L.) Burm.f. leaf extract ( $A$. vera leaf juice - $99.5 \%$, citric acid - $0.3 \%$, sodium benzoate $0.1 \%$, potassium sorbate $-0.05 \%)$, Morinda citrifolia $\mathrm{L}$. fruit extract (M. citrifolia fruit extract - 1.75-3 \%, propylene glycol - 70-90 \%, aqua - 10-30 \%, sodium benzoate 0.1-0.3\%, potassium sorbate - 0.1-0.3\%), and disinfectant Huva-San TR 50 (hydrogen peroxide $-50 \%$, stabilized with silver ions $-0.036 \%$ ) were used for seed treatment.

\section{Methods}

The untreated seeds were soaked in Huva-San TR 50 and plant extracts solutions ( $1 \mathrm{~g}$ of seeds per $100 \mathrm{ml}$ of the solution) for $30 \mathrm{~min}$. Huva-San TR 50 was applied at concentrations of $0.025,0.05$ and $0.1 \%$, recommended by the producer. The same concentrations were used for plant extracts. Controls included untreated seeds (control) and seeds soaked in distilled water for $30 \mathrm{~min}$ (water control). Seeds treated with Huva-San TR 50 and plant extracts, as well as seeds soaked in water, after treatment were drained on the sieve and next surface dried for $30 \mathrm{~min}$ on sterilized blotter paper. Seed germination, vigour and health were evaluated for untreated and treated seeds.

Seed germination was evaluated according to ISTA Rules [45]. For each treatment 300 seeds (six replicates of 50 seeds) were tested. Seeds were placed in $9 \mathrm{~cm}$ diameter Petri dishes (50 seeds per dish), on 6 layers of blotter paper moistened with distilled water, and incubated at $20{ }^{\circ} \mathrm{C}$ in darkness for 14 days. Germination at the first count (the percentage of normal seedlings) was evaluated after 7 days of incubation, while germination at the final count (total percentage of normal seedlings), the percentages of abnormal diseased seedlings, abnormal deformed seedlings, fresh seeds and dead seeds were determined after 14 days. Additionally, the percentage of germinating seeds $\left(G_{\max }\right)$ was calculated on the base of seed vigour test.

To evaluate seed vigour six replicates of 50 seeds were tested for each treatment [46]. Seeds were placed in $9 \mathrm{~cm}$ diameter Petri dishes (50 seeds per dish), on 6 layers of blotter paper moistened with distilled water, and incubated at $20{ }^{\circ} \mathrm{C}$ in darkness. Germinating 
seeds (with the radicle at least $1 \mathrm{~mm}$ long) were counted daily for 14 days. The speed and uniformity of germination i.e. $T_{10}$ - time to $10 \%$ of $G_{\max }, T_{75}$ - time to $75 \%$ of $G_{\max }, M G T$ mean germination time, $U_{75-25}$ - time between 25 and $75 \%$ of $G_{\max }$ were calculated using Germinator software [47].

Deep-freeze blotter test was applied to assess seed infestation with fungi. The analysis was performed on 200 seeds (four replicates of 50 seeds) for each treatment. The seeds were placed in $9 \mathrm{~cm}$ diameter Petri dishes on six layers of blotter moistened with distilled water, 20 seeds per dish. The seeds were incubated for three days at $20{ }^{\circ} \mathrm{C}$ in darkness, next frozen at $20^{\circ} \mathrm{C}$ for $24 \mathrm{~h}$, and then incubated at $20^{\circ} \mathrm{C}$ under $12 \mathrm{~h}$ alternating cycles of NUV (Near Ultraviolet) light and darkness. Fungi were determined on the base of their growth and sporulation using a stereomicroscope and a compound microscope. Alternaria dauci and $A$. radicina were identified according to ISTA methodology $[48,49]$ and other fungi by means of ISTA manuals for identification of seed-borne pathogens and saprotrophs [50, 51]. The percentages of seeds infested with individual fungi were determined.

The results obtained were evaluated by one-way analysis of variance followed by Duncan's multiple range test, at a level $\alpha=0.05$. Parameters characterising seed vigour were calculated using Germinator software [46].

\section{Results}

Tested samples varied significantly in seed quality. Sample I was characterized by lower germination at the first and the final counts than sample II, which was correlated with higher numbers of abnormal diseased seedlings and dead seeds (Table 1). The decrease in the percentage of germinating seeds $\left(G_{\max }\right)$ in relation to untreated seeds, was observed only when sample II seeds were soaked in $0.1 \%$ solution of Aloe extract. Other treatments did not affect this parameter.

Treating seeds with Indian mulberry extract, in all applied concentrations, improved seed germination at the first and the final counts in sample I, whereas did not affect these parameters in sample II. However, the highest values of both parameters were observed when $0.025 \%$ solution of the extract was used. The significant increase in germination at the first count, as well as germination at the final count, was observed also when seeds of sample I were treated with $0.1 \%$ Aloe extract. Moreover, treating seeds of sample I with Morinda extract solutions at all concentrations resulted in the significant decrease in the percentage of abnormal diseased seedlings, and in case of 0.025 and $0.05 \%$ solutions, the percentage of dead seeds was reduced too. The decrease in the number of dead seeds in this sample was also observed after treatment with Huva-San TR 50 at concentrations of 0.025 and $0.1 \%$, and after soaking seeds in $0.1 \%$ Aloe extract. The increase in the percentage of fresh seeds was statistically significant when sample I seeds were treated with 0.025 and $0.1 \%$ solutions of Huva-San TR 50 and $0.025 \%$ solutions of both plant extracts. In sample II the increase in the percentage of fresh seeds was found after soaking the seeds in $0.1 \%$ solution of Aloe extract and $0.05 \%$ solution of Morinda extract. Although none of the applied treatments affected germination at the final count of sample II seeds, the decrease in the percentage of abnormal diseased seedlings was recorded for seeds treated with $0.1 \%$ Aloe and $0.025 \%$ Morinda extracts. 
Effects of plant extracts and Huva-San TR 50 on seed germination

\begin{tabular}{|c|c|c|c|c|c|c|c|}
\hline Treatments & $\begin{array}{c}G_{\max } \\
{[\%]}\end{array}$ & $\begin{array}{c}\text { Germination } \\
\text { at the first } \\
\text { count } \\
{[\%]} \\
\end{array}$ & $\begin{array}{c}\text { Germination } \\
\text { at the final } \\
\text { count } \\
{[\%]}\end{array}$ & $\begin{array}{c}\text { Abnormal } \\
\text { diseased } \\
\text { seedlings } \\
{[\%]} \\
\end{array}$ & $\begin{array}{c}\text { Abnormal } \\
\text { deformed } \\
\text { seedlings } \\
{[\%]} \\
\end{array}$ & $\begin{array}{c}\text { Fresh } \\
\text { seeds } \\
{[\%]}\end{array}$ & $\begin{array}{c}\text { Dead } \\
\text { seeds } \\
{[\%]}\end{array}$ \\
\hline & \multicolumn{7}{|c|}{ Sample I } \\
\hline $\mathrm{C}$ & $78.7 \mathrm{ab}$ & $26.0 \mathrm{a}$ & $27.7 \mathrm{a}$ & $49.3 \mathrm{~d}$ & $0.3 \mathrm{a}$ & $8.0 \mathrm{a}$ & $14.7 \mathrm{c}$ \\
\hline WC & $77.7 \mathrm{ab}$ & $31.3 \mathrm{a}-\mathrm{c}$ & $35.3 \mathrm{a}-\mathrm{c}$ & $38.3 \mathrm{~b}-\mathrm{d}$ & $0.3 \mathrm{a}$ & $12.7 \mathrm{a}-\mathrm{c}$ & $13.3 \mathrm{bc}$ \\
\hline A $0.025 \%$ & $81.7 \mathrm{~b}$ & $26.0 \mathrm{a}$ & $28.3 \mathrm{ab}$ & $39.3 \mathrm{~b}-\mathrm{d}$ & $1.7 \mathrm{a}$ & $18.7 \mathrm{c}$ & $12.0 \mathrm{a}-\mathrm{c}$ \\
\hline A $0.05 \%$ & $81.7 \mathrm{~b}$ & $29.0 \mathrm{ab}$ & $31.0 \mathrm{ab}$ & $43.0 \mathrm{~cd}$ & $1.3 \mathrm{a}$ & $14.0 \mathrm{a}-\mathrm{c}$ & $10.7 \mathrm{a}-\mathrm{c}$ \\
\hline A $0.1 \%$ & $79.3 \mathrm{~b}$ & $34.6 \mathrm{bc}$ & $38.3 \mathrm{bc}$ & $40.3 \mathrm{c}-\mathrm{d}$ & $0.3 \mathrm{a}$ & $11.3 \mathrm{a}-\mathrm{c}$ & $9.7 \mathrm{ab}$ \\
\hline M $0.025 \%$ & $79.3 \mathrm{~b}$ & $46.3 \mathrm{~d}$ & $49.0 \mathrm{~d}$ & $24.3 \mathrm{a}$ & $1.3 \mathrm{a}$ & $16.0 \mathrm{bc}$ & $9.3 \mathrm{ab}$ \\
\hline M $0.05 \%$ & $70.0 \mathrm{a}$ & $37.6 \mathrm{c}$ & $44.0 \mathrm{~cd}$ & $32.7 \mathrm{a}-\mathrm{c}$ & $1.3 \mathrm{a}$ & $13.7 \mathrm{a}-\mathrm{c}$ & $8.3 \mathrm{a}$ \\
\hline M $0.1 \%$ & $74.3 \mathrm{ab}$ & $39.0 \mathrm{~cd}$ & $43.0 \mathrm{~cd}$ & $31.3 \mathrm{ab}$ & $1.0 \mathrm{a}$ & $13.0 \mathrm{a}-\mathrm{c}$ & $11.7 \mathrm{a}-\mathrm{c}$ \\
\hline HS $0.025 \%$ & $74.3 \mathrm{ab}$ & $24.3 \mathrm{a}$ & 34.7 a-c & $38.3 \mathrm{~b}-\mathrm{d}$ & $1.0 \mathrm{a}$ & $17.3 \mathrm{bc}$ & $8.3 \mathrm{ab}$ \\
\hline HS $0.05 \%$ & $79.7 \mathrm{~b}$ & $31.3 \mathrm{a}-\mathrm{c}$ & $34.0 \mathrm{a}-\mathrm{c}$ & $39.0 \mathrm{~b}-\mathrm{d}$ & $0.7 \mathrm{a}$ & $11.0 \mathrm{ab}$ & $15.3 \mathrm{c}$ \\
\hline \multirow[t]{2}{*}{ HS $0.1 \%$} & $79.0 \mathrm{ab}$ & $24.0 \mathrm{a}$ & $36.7 \mathrm{a}-\mathrm{c}$ & $37.7 \mathrm{~b}-\mathrm{d}$ & $0.7 \mathrm{a}$ & $16.7 \mathrm{bc}$ & $8.3 \mathrm{a}$ \\
\hline & \multicolumn{7}{|c|}{ Sample II } \\
\hline $\mathrm{C}$ & $81.0 \mathrm{~b}$ & $55.3 \mathrm{a}$ & $65.7 \mathrm{a}$ & $14.0 \mathrm{c}$ & $0 \mathrm{a}$ & $10.0 \mathrm{a}$ & $10.3 \mathrm{a}$ \\
\hline $\mathrm{WC}$ & $77.0 \mathrm{ab}$ & $54.3 \mathrm{a}$ & $64.3 \mathrm{a}$ & $13.0 \mathrm{c}$ & $0 \mathrm{a}$ & $13.7 \mathrm{ab}$ & $9.0 \mathrm{a}$ \\
\hline A $0.025 \%$ & $77.3 \mathrm{ab}$ & $61.7 \mathrm{a}$ & $68.3 \mathrm{a}$ & $10.0 \mathrm{a}-\mathrm{c}$ & $0 \mathrm{a}$ & $15.0 \mathrm{ab}$ & $6.7 \mathrm{a}$ \\
\hline A $0.05 \%$ & $76.7 \mathrm{ab}$ & $57.0 \mathrm{a}$ & $63.7 \mathrm{a}$ & $11.0 \mathrm{a}-\mathrm{c}$ & $0 \mathrm{a}$ & $16.3 \mathrm{ab}$ & $9.0 \mathrm{a}$ \\
\hline A $0.1 \%$ & $74.0 \mathrm{a}$ & $61.3 \mathrm{a}$ & $68.3 \mathrm{a}$ & $5.7 \mathrm{a}$ & $0 \mathrm{a}$ & $18.7 \mathrm{~b}$ & $7.3 \mathrm{a}$ \\
\hline M $0.025 \%$ & $79.7 \mathrm{ab}$ & $58.7 \mathrm{a}$ & $68.7 \mathrm{a}$ & $6.3 \mathrm{ab}$ & $0.3 \mathrm{~b}$ & $16.0 \mathrm{ab}$ & $8.7 \mathrm{a}$ \\
\hline M $0.05 \%$ & $77.7 \mathrm{ab}$ & $56.3 \mathrm{a}$ & $66.0 \mathrm{a}$ & $8.3 \mathrm{a}-\mathrm{c}$ & $0 \mathrm{a}$ & $18.3 \mathrm{~b}$ & $7.3 \mathrm{a}$ \\
\hline M $0.1 \%$ & $79.0 \mathrm{ab}$ & $60.0 \mathrm{a}$ & $65.3 \mathrm{a}$ & $11.7 \mathrm{bc}$ & $0 \mathrm{a}$ & $13.3 \mathrm{ab}$ & $9.7 \mathrm{a}$ \\
\hline HS $0.025 \%$ & $76.3 \mathrm{ab}$ & $53.7 \mathrm{a}$ & $60.3 \mathrm{a}$ & $13.3 \mathrm{c}$ & $0 \mathrm{a}$ & $15.3 \mathrm{ab}$ & $11.0 \mathrm{a}$ \\
\hline HS $0.05 \%$ & $78.7 \mathrm{ab}$ & $57.7 \mathrm{a}$ & $66.0 \mathrm{a}$ & $11.0 \mathrm{a}-\mathrm{c}$ & $0 \mathrm{a}$ & $13.0 \mathrm{a}$ & $10.0 \mathrm{a}$ \\
\hline HS $0.1 \%$ & $82.7 \mathrm{~b}$ & $52.0 \mathrm{a}$ & $62.0 \mathrm{a}$ & $10.7 \mathrm{a}-\mathrm{c}$ & $0 \mathrm{a}$ & $16.0 \mathrm{ab}$ & $11.3 \mathrm{a}$ \\
\hline
\end{tabular}

Means in columns, for each sample separately, followed by the same letters are not significantly different at $\alpha=0.05$ level according to Duncan's test. $G_{\max }$ - the percentage of germinating seeds, C - control - untreated seeds, WC - water control - seeds soaked in distilled water for $30 \mathrm{~min}, \mathrm{M} 0.025 \%$, M $0.05 \%, \mathrm{M} 0.1 \%$ - seeds soaked in $0.025 \%, 0.05 \%$ and $0.1 \%$ Morinda extracts, respectively, A $0.025 \%$, A $0.05 \%$, A $0.1 \%$ - seeds soaked in $0.025 \%, 0.05 \%$ and $0.1 \%$ Aloe extracts, respectively, HS $0.025 \%$, HS $0.05 \%$, HS $0.1 \%$ - seeds soaked in $0.025 \%, 0.05 \%$ and $0.1 \%$ Huva-San TR 50 solutions, respectively

Generally, the treatments did not affect speed of seed germination in both samples (Table 2). The significant deterioration of mean germination time (MGT) was observed only when sample I seeds were treated with $0.1 \%$ solution of Aloe extract, while soaking in $0.05 \%$ solution of this extract significantly improved vigour of sample II seeds, expressed by $T_{75}$ parameter. None of the treatments affected uniformity $\left(U_{75-25}\right)$ of seed germination, as well as $T_{10}$ parameter, in both samples.

Alternaria alternata (Fr.) Keissler was recorded on almost all untreated seeds of both samples, but significantly higher seed infestation with Alternaria radicina Meier, Drechsler \& E.D. Edd, Cladosporium spp., Melanospora simplex (Corda) D. Hawksw. and Stemphylium botryosum Wallr. was observed in sample I (Table 3).

On the contrary, a higher number of seeds infested with Fusarium spp. was detected in sample II. Alternaria dauci (J.G. Kühn) J.W. Groves \& Skolko was observed only in sample I, and infected a relatively low percentage of seeds (maximum $1.5 \%$ ). Additionally, the pathogen was not found on untreated seeds, but in case when seeds were treated with $0.025 \%$ and $0.05 \%$ Huva-San TR 50 and $0.05 \%$ and $0.1 \%$ Aloe extract. Soaking sample I 
seeds in the solutions of both plant extracts, regardless of their concentration, significantly limited seed infestation with A. alternata in relation to control. Treating seeds with $0.025 \%$ Huva-San TR 50, $0.05 \%$ Aloe extract and $0.025 \%$ and $0.05 \%$ Indian mulberry extract decreased significantly the percentage of seeds infected by A. radicina in this sample. On the other hand, none of the treatments affected seed infestation with Alternaria spp. in sample II. Fungi from genus Cladosporium were detected on $29.5 \%$ and $4.5 \%$ of untreated seeds of samples I and II, respectively.

Table 2

Effects of plant extracts and Huva-San TR 50 on seed vigour

\begin{tabular}{|c|c|c|c|c|}
\hline \multirow{2}{*}{ Treatments } & \multicolumn{3}{|c|}{ Speed of germination [days] } & \multirow{2}{*}{$\begin{array}{c}\begin{array}{c}\text { Uniformity of } \\
\text { germination } \\
\text { [days] }\end{array} \\
U_{75-25} \\
\end{array}$} \\
\hline & $T_{10}$ & $T_{75}$ & $M G T$ & \\
\hline & \multicolumn{4}{|c|}{ Sample I } \\
\hline $\mathrm{C}$ & $2.18 \mathrm{ab}$ & $3.13 \mathrm{ab}$ & $2.97 \mathrm{ab}$ & $0.82 \mathrm{ab}$ \\
\hline WC & $2.11 \mathrm{a}$ & $3.18 \mathrm{ab}$ & $2.92 \mathrm{ab}$ & $0.82 \mathrm{ab}$ \\
\hline A $0.025 \%$ & $2.17 \mathrm{ab}$ & $3.12 \mathrm{ab}$ & $2.83 \mathrm{a}$ & $0.73 \quad \mathrm{a}$ \\
\hline A $0.05 \%$ & $2.13 \mathrm{a}$ & $3.12 \mathrm{ab}$ & $2.83 \mathrm{a}$ & $0.73 \quad \mathrm{a}$ \\
\hline A $0.1 \%$ & $2.32 \mathrm{~b}$ & $3.38 \mathrm{~b}$ & $3.15 \mathrm{c}$ & $0.81 \mathrm{ab}$ \\
\hline M $0.025 \%$ & $2.09 \quad \mathrm{a}$ & $3.07 \mathrm{a}$ & $2.84 \mathrm{a}$ & $0.75 \mathrm{ab}$ \\
\hline $\mathrm{M} 0.05 \%$ & $2.18 \mathrm{ab}$ & $3.19 \mathrm{ab}$ & $2.90 \mathrm{ab}$ & $0.75 \mathrm{ab}$ \\
\hline M $0.1 \%$ & $2.18 \mathrm{ab}$ & $3.29 \mathrm{ab}$ & $3.03 \mathrm{bc}$ & $0.85 \mathrm{ab}$ \\
\hline HS $0.025 \%$ & $2.00 \mathrm{a}$ & $3.25 \mathrm{ab}$ & $2.92 \mathrm{ab}$ & $0.95 \mathrm{~b}$ \\
\hline HS $0.05 \%$ & $2.09 \mathrm{a}$ & $3.14 \mathrm{ab}$ & $2.80 \quad \mathrm{a}$ & $0.75 \mathrm{ab}$ \\
\hline \multirow[t]{2}{*}{ HS $0.1 \%$} & $2.05 \mathrm{a}$ & $3.12 \mathrm{ab}$ & $2.82 \mathrm{a}$ & $0.80 \mathrm{ab}$ \\
\hline & \multicolumn{4}{|c|}{ Sample II } \\
\hline $\mathrm{C}$ & $1.82 \mathrm{a}$ & $2.91 \mathrm{~b}$ & $2.64 \mathrm{a}$ & $0.84 \quad \mathrm{a}$ \\
\hline WC & $1.82 \mathrm{a}$ & $2.91 \mathrm{~b}$ & $2.66 \mathrm{a}$ & $0.85 \mathrm{a}$ \\
\hline A $0.025 \%$ & $1.82 \mathrm{a}$ & $2.54 \mathrm{ab}$ & $2.49 \mathrm{a}$ & $0.58 \quad \mathrm{a}$ \\
\hline A $0.05 \%$ & $1.78 \mathrm{a}$ & $2.58 \mathrm{a}$ & $2.47 \quad \mathrm{a}$ & $0.64 \quad \mathrm{a}$ \\
\hline A $0.1 \%$ & $1.73 \mathrm{a}$ & $2.65 \mathrm{ab}$ & $2.43 \quad \mathrm{a}$ & $0.71 \quad \mathrm{a}$ \\
\hline M $0.025 \%$ & $1.84 \mathrm{a}$ & $2.67 \mathrm{ab}$ & $2.53 \mathrm{a}$ & $0.65 \mathrm{a}$ \\
\hline M $0.05 \%$ & $1.89 \mathrm{a}$ & $2.66 \mathrm{ab}$ & $2.53 \mathrm{a}$ & $0.61 \quad \mathrm{a}$ \\
\hline M $0.1 \%$ & $1.77 \quad \mathrm{a}$ & $2.73 \mathrm{ab}$ & $2.50 \quad \mathrm{a}$ & $0.74 \quad \mathrm{a}$ \\
\hline HS $0.025 \%$ & $1.88 \mathrm{a}$ & $2.58 \mathrm{ab}$ & $2.58 \mathrm{a}$ & $0.59 \mathrm{a}$ \\
\hline HS $0.05 \%$ & $1.80 \quad \mathrm{a}$ & $2.79 \mathrm{ab}$ & $2.64 \mathrm{a}$ & $0.79 \quad \mathrm{a}$ \\
\hline HS $0.1 \%$ & $1.81 \mathrm{a}$ & $2.61 \mathrm{ab}$ & $2.49 \mathrm{a}$ & $0.63 \mathrm{a}$ \\
\hline
\end{tabular}

Means in columns, for each sample separately, followed by the same letters are not significantly different at $\alpha=0.05$ level according to Duncan's test. $T_{10}$ - time to $10 \%$ of $G_{\max }, T_{75}$ - time to $75 \%$ of $G_{\max }, M G T$ - mean germination time, $U_{75-25}$ - time between 25 and $75 \%$ of $G_{\max }$. For other explanations see Table 1

The percentage of seeds infested with these fungi decreased significantly, when seeds of sample I were soaked in $0.025 \%$ Aloe and $0.1 \%$ Morinda extracts, whereas treatment with $0.05 \%$ Morinda extract eradicated completely Cladosporium spp. from sample II seeds. In few cases applied treatments caused an increase in seed infestation with Fusarium spp. It was observed for sample I seeds soaked in $0.05 \%$ Aloe extract and in case of sample II seeds treated with $0.025 \%$ Huva-San TR 50 and with $0.025 \%$ and $0.1 \%$ Aloe extracts. In sample I soaking seeds in $0.025 \%$ solution of Huva-San TR 50 increased seed infestation with $M$. simplex, whereas $0.05 \%$ Huva-San TR 50 and $0.05 \%$ Aloe extract treatments significantly decreased the presence of this fungus. In case of sample II, all 
solutions of Aloe extract, as well as Huva-San TR 50 at concentrations of $0.025 \%$ and $0.1 \%$, and Morinda extract at concentration $0.1 \%$ effectively controlled M. simplex. Stemphylium botryosum was recorded on a small number of sample II seeds and none of the treatments affected its presence. On the contrary, $22 \%$ of untreated seeds of sample I was infested with this fungus, and treatment with $0.05 \%$ and $0.1 \%$ Huva-San TR 50, as well as $0.025 \%$ Morinda extract reduced its incidence to $9.0 \%, 6.5 \%$ and $11.0 \%$, respectively.

Table 3

Effects of plant extracts and Huva-San TR 50 on seed infestation with fungi (the percentage of infested seeds)

\begin{tabular}{|c|c|c|c|c|c|c|c|}
\hline Treatments & $\begin{array}{c}\text { Alternaria } \\
\text { alternata }\end{array}$ & $\begin{array}{c}\text { Alternaria } \\
\text { dauci }\end{array}$ & $\begin{array}{l}\text { Alternaria } \\
\text { radicina }\end{array}$ & $\begin{array}{c}\text { Cladosporium } \\
\text { spp. }\end{array}$ & $\begin{array}{c}\text { Fusarium } \\
\text { spp. }\end{array}$ & $\begin{array}{l}\text { Melanospora } \\
\text { simplex }\end{array}$ & $\begin{array}{c}\text { Stemphylium } \\
\text { botryosum }\end{array}$ \\
\hline & \multicolumn{7}{|c|}{ Sample I } \\
\hline $\mathrm{C}$ & 98.0 & $0 \quad \mathrm{a}$ & $37.0 \mathrm{c}$ & $29.5 \mathrm{~cd}$ & $2.5 \mathrm{a}$ & $19.5 \mathrm{~b}$ & $22.0 \mathrm{c}$ \\
\hline $\mathrm{WC}$ & $97.5 \mathrm{bc}$ & $0 \mathrm{a}$ & 27.0 a-c & 24.5 a-d & $2.5 \mathrm{a}$ & $19.0 \mathrm{~b}$ & 13.0 a-c \\
\hline A $0.025 \%$ & $90.5 \mathrm{a}$ & $\begin{array}{ll}0 & \mathrm{a} \\
\end{array}$ & $24.5 \quad a-c$ & $17.5 \mathrm{a}$ & $3.0 \mathrm{a}$ & $15.0 \mathrm{ab}$ & 15.0 bc \\
\hline A $0.05 \%$ & $91.0 \mathrm{a}$ & $0.5 \mathrm{ab}$ & $20.5 \mathrm{a}$ & $28.5 \mathrm{c}-\mathrm{d}$ & $35.5 \mathrm{~b}$ & $9.5 \mathrm{a}$ & $14.0 \mathrm{bc}$ \\
\hline A $0.1 \%$ & $91.5 \mathrm{a}$ & $1.0 \mathrm{ab}$ & 32.0 a-c & 19.0 a-c & $4.5 \mathrm{a}$ & $18.0 \mathrm{~b}$ & $14.0 \mathrm{bc}$ \\
\hline M $0.025 \%$ & $92.0 \mathrm{a}$ & $0 \quad \mathrm{a}$ & $23.0 \mathrm{ab}$ & 27.5 a-d & $3.5 \mathrm{a}$ & $12.0 \mathrm{ab}$ & $11.0 \mathrm{ab}$ \\
\hline M $0.05 \%$ & $93.5 \mathrm{ab}$ & $0 \quad \mathrm{a}$ & $24.0 \mathrm{ab}$ & 27.0 a-d & $2.5 \mathrm{a}$ & $15.5 \mathrm{ab}$ & $15.5 \mathrm{bc}$ \\
\hline M $0.1 \%$ & $92.5 \mathrm{ab}$ & $0 \quad \mathrm{a}$ & 28.0 a-c & $19.5 \mathrm{ab}$ & $5.0 \mathrm{a}$ & $19.0 \mathrm{~b}$ & $13.5 \mathrm{a}-\mathrm{c}$ \\
\hline HS $0.025 \%$ & $95.0 \mathrm{a}-\mathrm{c}$ & $1.5 \mathrm{~b}$ & $21.0 \quad \mathrm{a}$ & $30.5 \mathrm{~d}$ & $5.0 \mathrm{a}$ & 30.5 & $12.5 \mathrm{a}-\mathrm{c}$ \\
\hline HS $0.05 \%$ & $94.5 \mathrm{a}-\mathrm{c}$ & $1.0 \mathrm{ab}$ & $34.0 \mathrm{bc}$ & $31.0 \mathrm{~d}$ & $3.5 \mathrm{a}$ & 9.5 & $9.0 \mathrm{ab}$ \\
\hline \multirow[t]{2}{*}{ HS $0.1 \%$} & $91.5 \mathrm{ab}$ & $0 \quad \mathrm{a}$ & $31.0 \quad \mathrm{a}-\mathrm{c}$ & 21.5 a-d & $5.5 \mathrm{a}$ & $12.0 \mathrm{ab}$ & $6.5 \mathrm{a}$ \\
\hline & \multicolumn{7}{|c|}{ Sample II } \\
\hline $\mathrm{C}$ & 99.5 & - & $2.5 \mathrm{ab}$ & $4.5 \mathrm{bc}$ & $22.5 \mathrm{a}$ & $16.5 \mathrm{~cd}$ & $2.0 \mathrm{a}$ \\
\hline WC & $100.0 \mathrm{a}$ & - & $5.0 \mathrm{~b}$ & $2.0 \mathrm{a}-\mathrm{c}$ & $21.5 \mathrm{a}$ & $9.5 \mathrm{~b}-\mathrm{d}$ & $0.5 \mathrm{a}$ \\
\hline A $0.025 \%$ & $100.0 \mathrm{a}$ & - & $1.0 \mathrm{a}$ & $3.5 \mathrm{a}-\mathrm{c}$ & $44.5 \mathrm{c}$ & $5.0 \mathrm{ab}$ & $2.5 \mathrm{a}$ \\
\hline A $0.05 \%$ & $98.5 \mathrm{a}$ & - & $2.0 \mathrm{ab}$ & $3.5 \mathrm{bc}$ & $24.0 \mathrm{ab}$ & $3.5 \mathrm{a}$ & $0.5 \mathrm{a}$ \\
\hline A $0.1 \%$ & 99.0 & - & $3.0 \mathrm{ab}$ & $1.5 \mathrm{ab}$ & $34.5 \mathrm{bc}$ & $5.5 \mathrm{ab}$ & $0.5 \mathrm{a}$ \\
\hline M $0.025 \%$ & $99.5 \mathrm{a}$ & - & $2.0 \mathrm{ab}$ & $3.5 \mathrm{a}-\mathrm{c}$ & $30.0 \mathrm{ab}$ & $9.0 \mathrm{bc}$ & $2.0 \mathrm{a}$ \\
\hline M $0.05 \%$ & 98.5 & - & $4.0 \mathrm{ab}$ & $\begin{array}{ll}0 & \mathrm{a} \\
\end{array}$ & $32.0 \mathrm{ab}$ & $17.0 \mathrm{~d}$ & $1.5 \mathrm{a}$ \\
\hline M $0.1 \%$ & 99.0 & - & $2.0 \mathrm{ab}$ & $0.5 \mathrm{ab}$ & $26.5 \mathrm{ab}$ & $7.0 \mathrm{ab}$ & $0.5 \mathrm{a}$ \\
\hline HS $0.025 \%$ & 99.5 & - & $3.5 \mathrm{ab}$ & $5.5 \mathrm{c}$ & $34.0 \mathrm{bc}$ & $4.5 \mathrm{ab}$ & $2.0 \mathrm{a}$ \\
\hline HS $0.05 \%$ & 99.5 & - & $2.5 \mathrm{ab}$ & $3.5 \mathrm{bc}$ & $26.0 \mathrm{ab}$ & $9.5 \mathrm{~b}-\mathrm{d}$ & $1.5 \mathrm{a}$ \\
\hline HS $0.1 \%$ & $99.0 \quad \mathrm{a}$ & - & $3.5 \mathrm{ab}$ & $1.0 \mathrm{ab}$ & $22.5 \mathrm{ab}$ & $6.5 \mathrm{ab}$ & $1.5 \mathrm{a}$ \\
\hline
\end{tabular}

Means in columns, for each sample separately, followed by the same letters are not significantly different at $\alpha=0.05$ level according to Duncan's test, “-“" not detected. For other explanations see Table 1

\section{Discussion}

It has been found in the present experiment that effectiveness of applied treatments was significantly connected with carrot seed quality before treatment. Sample I, which was characterized by poor germination and abundant infestation with fungi, especially A. radicina, responded to the treatments to a greater extent than sample II, showing relatively higher germination and lower infection by pathogenic Alternaria spp. The similar correlation was observed previously in relation to zinnia seeds treated with hydrogen peroxide. The sample showing high seed infestation with fungi, including Alternaria spp., responded better to $\mathrm{H}_{2} \mathrm{O}_{2}$ treatment, than the sample free of pathogenic Alternaria zinniae and with a high initial germination. The treatment also negatively affected seed germination at the final count of the initially better sample [27]. 
The results of current experiment showed that soaking sample I seeds in the solutions of both plant extracts, in all applied concentrations, significantly limited seed infestation with A. alternata compared to control. Moreover, the reduction in the incidence of A. radicina, the important carrot seed-borne pathogen, was observed when $0.05 \%$ solution of Aloe extract, and 0.025 and $0.05 \%$ solutions of Indian mulberry extract were applied. Seed health improvement resulted in the increase in seed germination at the first and the final counts. Tylkowska [2] reported that the increase in carrot seed infestation with A. radicina by $1 \%$ reduced germination at the final count by $0.3 \%$. Additionally, Szopinska et al. [26] frequently detected A. alternata, A. dauci and A. radicina on diseased seedlings in the emergence test. Therefore, control of these fungi seems to be very important for carrot seed production. The inhibitory effect of Aloe and Indian mulberry extracts against $A$. alternata was observed by other researchers. Bhosale et al. [20] demonstrated antifungal activity of $M$. citrifolia extract in relation to Alternaria alternata, Aspergillus flavus and A. niger, isolated from groundnut (Arachis hypogaea L.) seeds. Saks and Barkai-Golan [11] who applied Aloe vera gel to control postharvest fungi: Penicillium digitatum, P. expansum, Botrytis cinerea and A. alternata, revealed that the gel suppressed germination and mycelial growth of all fungi, but $P$. digitatum and A. alternata were the most sensitive species. Both Aloe and Indian mulberry extracts contain numerous antifungal compounds, among them phenolic acids and flavonoids. According to Aguilar et al. [52] the antifungal activity of these extracts can be explained by the ability of phenols to form complexes with polysaccharides and proteins of external layers of the fungal cells. In this way the function of cell walls and membranes is destabilized causing the death of the microorganism.

In vitro study of Bajwa et al. [13] showed antifungal activity of aqueous and organic Aloe vera shoot extracts against pathogenic Alternaria spp. (A. alternata, A. citri, A. tenuissima). Both extracts significantly inhibited growth and biomass production of all tested fungi, but the effect depended on the applied concentration (2, 4, 6, $8 \%$ ). Several authors showed that the concentration of Aloe and Morinda extracts had a considerable impact on their antimicrobial activity [11, 15, 18, 19]. For instance, Usha et al. [19] found that the growth of Escherichia coli, Staphylococcus aureus, Candida albicans and Aspergillus niger colonies decreased with the increasing concentration of Morinda leaf extract. Sitara et al. [15], who evaluated the effect of 0.15, 0.25 and $0.35 \%$ Aloe extracts on the growth of Aspergillus niger, A. flavus, A. alternata, Drechslera hawaiensis and Penicillium digitatum on PDA medium, reported that the extract at the highest concentration completely inhibited the growth of D. hawaiensis and A. alternata. In our experiment the relation between plant extracts concentration and its effectiveness was not so obvious, in some cases the highest efficacy revealed lower concentrated plant extracts. For example, sample I seeds treated with $0.05 \%$ Aloe extract showed lower infestation with A. radicina and Melanospora simplex than seeds soaked in $0.1 \%$ solution of this extract. On the other hand, the limited growth of these fungi was probably the effect of excessive development of Fusarium spp., which competed with other fungi on those seeds. We observed in our previous studies, that soaking seeds in aqueous solutions may favour spread of infection in case of superficially located fungi, such as Fusarium spp. [26, 27]. Moreover, dose-dependent reaction discussed above, was observed by other authors mostly in in vitro assays, in which the mechanism of competition does not exist.

Numerous reports confirm antimicrobial properties of $\mathrm{H}_{2} \mathrm{O}_{2}$ [26-30]. Hydrogen peroxide at concentrations of 3, 6, 9 and $12 \%$ effectively controlled A. alternata, A. dauci 
and $A$. radicina on carrot seeds [26], as well as A. zinniae and Fusarium spp. on zinnia seeds [27]. Treating pearl millet seeds with $1 \mathrm{mM} \mathrm{H}_{2} \mathrm{O}_{2}$ efficiently suppressed development of downy mildew caused by Sclerospora graminicola Sacc. [28]. Smilanick et al. [30] reported that soaking wheat and barley grains in $3.5 \% \mathrm{H}_{2} \mathrm{O}_{2}$ completely inhibited growth of Tilletia controversa and T. tritici spores. Results of Angelova et al. [53] indicate that exposure of fungal spores to $\mathrm{H}_{2} \mathrm{O}_{2}$ promoted oxidative stress evidenced by inhibition of spore germination and biomass production. Oliveira et al. [54] reported that $\mathrm{H}_{2} \mathrm{O}_{2}$ induces conidia cell death in a dose-dependent manner and through a secondary necrosis mechanism.

Wojdyla [55] found that rising the concentration of the preparation Huva-San TR 50 (a.i. $\mathrm{H}_{2} \mathrm{O}_{2}$ and silver ions) from 0.025 to $0.1 \%$ resulted in a significant increase in its effectiveness against Sphaerotheca pannosa var. rosae (powdery mildew) on roses and Oidium spp. on cissus plants. In our study the biggest reduction in seed infestation with A. radicina was observed after treating carrot seeds with Huva-San TR 50 at the lowest concentration $(0.025 \%)$, what was connected with the increase in the incidence of Melanospora simplex. It seems possible that both plant extracts as well as Huva-San TR 50, applied at lower concentrations, favoured growth of non-pathogenic fungi, which competed with seed-borne pathogens.

In our experiment treatments with $M$. citrifolia fruit extract significantly improved seed germination in sample I. This beneficial effect was probably connected not only with a reduction in seed infestation with Alternaria spp., what we mentioned above, but also with an antioxidative activity of this extract. Indian mulberry extract contains several flavonoids (i.a. kaempferol, rutin, quercetin, narcissoide) and vitamins (i.a. ascorbic acid, tocopherol) on proven antioxidant properties [4]. Aloe extract, which improved seed germination at the highest concentration, also contains numerous antioxidants, such as phenolic acids and flavonoids [3].

It has been found that seed germination at the final count in sample I after Huva-San TR 50 treatments was higher by 6.3 to $9.0 \%$ compared to untreated seeds. However, the results were not statistically proven. Hydrogen peroxide may enhance seed germination by control of seed-borne pathogens, what has been mentioned above, and additionally by oxidation of germination inhibitors present in the pericarp [26-30, 41]. In the face of the fact that applied concentrations of Huva-San TR 50 did not affect negatively seed germination, the use of higher doses of this preparation or/and prolongation of seed exposition should be considered in the future experiments.

\section{Conclusion}

1. Treating seeds of sample I with Morinda citrifolia plant extract at concentrations of 0.025 and $0.05 \%$ reduced their infestation with Alternaria alternata and $A$. radicina, increased germination at the first and the final counts, and did not affect seed vigour.

2. The effects of Aloe extract and disinfectant Huva-San TR 50 on seed quality parameters varied depending on their concentration. Hence, further studies are necessary to establish the optimal conditions for carrot seed treatment. 


\section{References}

[1] Tülek S, Dolar FS. Detection and identification of Alternaria species causing diseases of carrot in Ankara province, Turkey. Horticulture. 2015;59:263-8. Available from: http://horticulturejournal.usamv.ro/ pdf/2015/art42.pdf.

[2] Tylkowska K. Carrot seed-borne diseases caused by Alternaria species. In: Chełkowski J, Visconti A, editors. Alternaria Biology, Plant Diseases and Metabolites. Elsevier Science Publishers; 1992. ISBN: 0444889981.

[3] Mikołajczak N. Potential health benefits of Aloe vera. J Educ Health Sport. 2018;8(9):1420-35. DOI: 10.5281/zenodo.1434046.

[4] Almeida ES, de Oliveira D, Hotza D. Properties and applications of Morinda citrifolia (noni): A review. Compr Rev Food Sci F. 2019;18:883-909. DOI: 10.1111/1541-4337.12456.

[5] Jasso de Rodríguez D, Hernández-Castillo D, Rodríguez-García R, Angulo-Sánchez JL. Antifungal activity in vitro of Aloe vera pulp and liquid fraction against plant pathogenic fungi. Ind Crops Prod. 2005;21:81-7. DOI: 10.1016/j.indcrop.2004.01.002.

[6] Hamman JH. Composition and applications of Aloe vera leaf gel. Molecules. 2008;13:1599-616. DOI: 10.3390/molecules13081599.

[7] Chauhan S, Gupta KC, Agraval M. Application of biodegradable Aloe vera gel to control post harvest decay and longer the shelf life of grapes. Int J Curr Microbiol Appl Sci. 2014;3(3):632-42. Available from: https://www.ijcmas.com/vol-3-3/Shweta\%20Chauhan,\%20et\%20al.pdf.

[8] Nidiry ESJ, Ganeshan G, Lokesha AN. Antifungal activity of some extractives and constituents of Aloe vera. Res J Med Plant. 2011;5(2):196-200. DOI: 10.3923/rjmp.2011.196.200.

[9] Marpudi SL, Abirami LSS, Pushkala R, Srividya N. Enhancement of storage life and quality maintenance of papaya fruits using Aloe vera based antimicrobial coating. Indian J Biotechnol. 2011;10:83-9. DOI: 10.1007/s10327-012-0380-z.

[10] Navarro D, Díaz-Mula HM, Guillén F, Zapata PJ, Castillo S, Serrano M, et al. Reduction of nectarine decay caused by Rhizopus stolonifer, Botrytis cinerea and Penicillium digitatum with Aloe vera gel alone and with addition of thymol. Int J Food Microbiol. 2011;151(2):241-6. DOI: 10.1016/j.ijfoodmicro.2011.09.009.

[11] Saks Y, Barkai-Golan R. Aloe vera gel activity against plant pathogenic fungi. Postharvest Biol Technol. 1995;6:159-65. DOI: 10.1016/0925-5214(94)00051-S.

[12] El-Samawaty AMA, Yassin MA, Bahkali A, Moslem M, Abd-Elslam KA. Bio-fungicidal activity of Aloe vera sap against mycotoxigenic seed-borne fungi. Fresenius Environ Bull. 2011;20(6):1352-9. Available from: https://www.prt-parlar.de/download_feb_2011/.

[13] Bajwa R, Shafique S, Shafique S. Appraisal of antifungal activity of Aloe vera. Mycopathology. 2007;5(1):5-9. Available from: https://pdfs.semanticscholar.org/1fe4/ c0fbd7f087080568bded5ab0f54f605ce5c1.pdf.

[14] Rosca-Casian O, Parvu M, Vlase L, Tamas M. Antifungal activity of Aloe vera leaves. Fitoterapia. 2007;78:219-22. DOI: 10.1016/j.fitote.2006.11.008.

[15] Sitara U, Hassan N, Naseem J. Antifungal activity of Aloe vera gel against plant pathogenic fungi. Pak J Bot. 2011;43(4):2231-3. Available from: http://www.pakbs.org/pjbot/PDFs/43(4)/PJB43(4)2231.pdf.

[16] Barani K, Manipal S, Prabu D, Ahmed A, Adusumili P, Jeevika C. Antifungal activity of Morinda citrifolia (noni) extracts against Candida albicans: An in vitro study. Indian J Dent Res. 2014;25(2):188-90. DOI: 10.4103/0970-9290.135918.

[17] Jayaraman SK, Manoharan MS, Illanchezian S. Antibacterial, antifungal and tumor cell suppression potential of Morinda citrifolia fruit extracts. Inter J Integr Biol. 2008;3(1):44-9. Available from: http://www.classicrus.com/IJIB/Arch/2008/1066.pdf.

[18] Srinivasahan V, Durairaj B. Antimicrobial activities of hydroethanolic extract of Morinda citrifolia fruit. Int J Curr Microbiol App Sci. 2014;3(9);26-33. Available from: https://www.ijcmas.com/vol-39/Vennila\%20Srinivasahan\%20and\%20Brindha\%20Durairaj.pdf.

[19] Usha R, Sashidharan S, Palaniswamy M. Antimicrobial activity of a rarely known species, Morinda citrifolia L. Ethnobot Leaflets. 2010;14:306-11. Available from: https://opensiuc.lib.siu.edu/cgi/ viewcontent.cgi?article $=1713 \&$ context $=$ ebl.

[20] Bhosale RP, Navgire KD, Rewale KA, Wahul SM. In vitro evaluation of various phytoextract against detected seed mycoflora of groundnut. Int J Curr Microbiol Appl Sci. 2018;7(10):1596-604. DOI: 10.20546/ijcmas.2018.710.180.

[21] Sunder J, Jeyakumar S, Kundu A, Srivastava RC, De AK. Effect of Morinda citrifolia extracts on in-vitro growth of Ralstonia solanacearum. Arch Appl Sci Res. 2011;3(3):394-402. Available from: https://www.researchgate.net/publication/267844467_Effect_of_Morinda_citrifolia_extracts_on_invitro_growth_of_Ralstonia_solanacearum. 
[22] Aji OR, Roosyidah LH. Antifungal activity of Morinda citrifolia leaf extract against Colletotrichum acutatum. Biogenesis. 2020;8(1):49-54. DOI: 10.24252/bio.v8i1.12009.

[23] Wojtyla Ł, Lechowska K, Kubala S, Garnczarska M. Different modes of hydrogen peroxide action during seed germination. Front Plant Sci. 2016;7:66. DOI: 10.3389/fpls.2016.00066.

[24] Martin NL, Bass P, Liss SN. Antibacterial properties and mechanism of activity of a novel silver-stabilized hydrogen peroxide. PLOS ONE. 2015;10(7):e0131345. DOI: 10.1371/journal.pone.0131345.

[25] Vatansever F, de Melo WC, Avci P, Vecchio D, Sadasivam M, Gupta A, et al. Antimicrobial strategies centered around reactive oxygen species - bactericidal antibiotics, photodynamic therapy, and beyond. FEMS Microbiol Rev. 2013;37(6):955-89. DOI: 10.1111/1574-6976.12026.

[26] Szopińska D, Jarosz M, Sławińska B. The effect of hydrogen peroxide on seed quality and emergence of carrot (Daucus carota L.). Acta Sci Pol Hortorum Cultus. 2017;16(2):21-33. Available from: http://wydawnictwo.up.wroc.pl/pl/action/getfull.php?id=5327.

[27] Szopińska D. Effects of hydrogen peroxide treatment on the germination, vigour and health of Zinnia elegans seeds. Folia Hort. 2014;26(1):19-29. DOI: 10.2478/fhort-2014-0002.

[28] Geetha HM, Shetty HS. Induction of resistance in pearl millet against downy mildew disease caused by Sclerospora graminicola using benzothiadiazole, calcium chloride and hydrogen peroxide - a comparative evaluation. Crop Prot. 2002;21(8):601-10. DOI: 10.1016/s0261-2194(01)00150-8.

[29] Peng M, Kuc J. Peroxidase-generated hydrogen peroxide as a source of antifungal activity in vitro and on tobacco leaf disks. Phytopathology. 1992;82:696-9. Available from: https://www.apsnet.org/publications/phytopathology/backissues/Documents/1992Articles/Phyto82n06_696. PDF.

[30] Smilanick JL, Goates BJ, Denis-Arrue R, Simmons GT, Peterson GL, Henson DJ, et al. Germinability of Tilletia spp. teliospores after hydrogen peroxide treatment. Plant Dis. 1994;78(9):861-865. Available from: https://www.apsnet.org/publications/plantdisease/backissues/Documents/1994Articles/PlantDisease78n09_8 61.pdf.

[31] Sharma S, Yadav S, Sibi G. Seed germination and maturation under the influence of hydrogene peroxide a review. J Crit Rev. 2020;7(1):6-10. DOI: 10.22159/jcr.07.01.03.

[32] Klein JD, Wood LA, Geneve RL. Hydrogen peroxide and color sorting improves germination and vigor of eastern gamagrass (Tripsacum dactyloides) seeds. Acta Hortic. 2008;782:93-8. DOI: 10.17660/ActaHortic.2008.782.8.

[33] Dufková H, Berka M, Luklová M, Rashotte AM, Brzobohatý B, Cerný M. Eggplant germination is promoted by hydrogen peroxide and temperature in an independent but overlapping manner. Molecules. 2019;24;4270. DOI: $10.3390 /$ molecules24234270.

[34] Wahid A, Sehar S, Perveen M, Gelani S, Basra SMA, Farooq M. Seed pretreatment with hydrogen peroxide improves heat tolerance in maize at germination and seedling growth stages. Seed Sci Technol. 2008;36(3):633-45. DOI: 10.15258/sst.2008.36.3.13.

[35] Conner PJ. Effects of stratification, germination temperature and pretreatment with gibberellic acid and hydrogen peroxide on germination of 'Fry' muscadine (Vitis rotundifolia) seed. HortSci. 2008;43(3):853-6. DOI: 10.21273/HORTSCI.43.3.853.

[36] Barba-Espín G, Hernández JA, Diaz-Vivancos P. Role of $\mathrm{H}_{2} \mathrm{O}_{2}$ in pea seed germination. Plant Signal Behav. 2012;7(2):193-5. DOI: 10.4161/psb.18881.

[37] Sasaki K, Kishtami S, Fumitaka A, Sato T. Promotion of seedling growth of seeds of rice (Oryza sativa L. cv. Hitomebore) by treatment with $\mathrm{H}_{2} \mathrm{O}_{2}$ before sowing. Plant Prod Sci. 2005;8(5):509-14. DOI: 10.1626/pps.8.509.

[38] Jaskani MJ, Kwon SW, Kim DH, Abbas H. Seed treatments and orientation affects germination and seedling emergence in tetraploid watermelon. Pakistan J Bot. 2006;38(1):89-98. Available from: http://www.pakbs.org/pjbot/PDFs/38(1)/PJB38(1)089.pdf.

[39] Ogawa K, Iwabuchi M. A mechanism for promoting the germination of Zinnia elegans seeds by hydrogen peroxide. Plant Cell Physiol. 2001;42(3):286-91. DOI: 10.1093/pcp/pce032.

[40] Ismail AA, Sidkey NM, Arafa RA, Fathy RM, El-Batal AI. Evaluation of in vitro activity of silver and selenium nanoparticles against Alternaria solani caused early blight disease on potato. British Biotechnol J. 2016;12(3):1-11. DOI: 10.9734/BBJ/2016/24155.

[41] Medda S, Hajra A, Dey U, Bose P, Mondal NK. Biosynthesis of silver nanoparticles from Aloe vera leaf extract and antifungal activity against Rhizopus sp. and Aspergillus sp. Appl Nanosci. 2015;5:875-80. DOI: 10.1007/s13204-014-0387-1.

[42] Pandey C, Khan E, Mishra A, Sardar M, Gupta M. Silver nanoparticles and its effect on seed germination and physiology in Brassica juncea L. (Indian mustard) plant. Adv Sci Lett. 2014;20(7/8/9):1673-6. DOI: 10.1166/asl.2014.5518. 
[43] El-Kadi SM, Mahmoud MK, Sayed-Ahmed KA, El-Hendawy MA. Comparison between silver nanoparticles and silver nitrate as antifungal agent. Int J Nanosci Nanoeng (IJNN). 2018;4(1):5-11. Available from: http://www.openscienceonline.com/journal/archive2 ?journalId=731\&paperId=4225.

[44] Vishwakarma K, Shweta, Upadhyay N, Singh J, Liu S, Singh VP, et al. Differential phytotoxic impact of plant mediated silver nanoparticles (AgNPs) and silver nitrate $\left(\mathrm{AgNO}_{3}\right)$ on Brassica sp. Front Plant Sci. 2017;8:1-12 Art. No. 1501. DOI: 10.3389/fpls.2017.01501.

[45] International Rules for Seed Testing. Chapter 5: The germination test 2020;1:i-1-14. DOI: 10.15258/istarules.2020.05.

[46] International Rules for Seed Testing. Chapter 15: Seed vigour testing 2020;1:i-5-20. DOI: 10.15258/istarules.2020.15.

[47] Joosen RVL, Kodde J, Willems L, Ligterink W, van der Plas LHW, Hilhorst HWM. Germinator: A software package for high-throughput scoring and curve fitting of Arabidopsis seed germination. Plant J. 2010;62:148-59. DOI: 10.1111/j.1365-313X.2009.04116.x.

[48] International Rules for Seed Testing. Chapter 7: Validated Seed Health Testing Methods. 7-001a: Detection of Alternaria dauci in Daucus carota (carrot) seed by blotter method. Bassersdorf, Switzerland: International Seed Testing Association; 2020. Available from: https://www.seedtest.org/upload/cms/user/ISTASHmethods20207-001a.pdf.

[49] International Rules for Seed Testing. Chapter 7: Validated Seed Health Testing Methods. 7-002a: Detection of Alternaria radicina in Daucus carota (carrot) seed by blotter method. Bassersdorf, Switzerland: International Seed Testing Association; 2020. Available from: https://www.seedtest.org/upload/cms/user/ISTASHmethods20207-002a.pdf.

[50] Watanabe T. Pictorial Atlas of Soil and Seed Fungi Morphologies of Cultured Fungi and Key to Species. Boca Raton, London, New York, Washington: CRC Press; 2002. ISBN: 0849311187.

[51] Mathur SB, Kongsdal O. Common laboratory seed health testing methods for detecting fungi. Bassersdorf, Switzerland: International Seed Testing Association; 2003, ISBN: 3906549356.

[52] Aguilar CN, Rodríguez R, Gutiérrez-Sánchez G, Augur C, Favela-Torres E, Prado-Barragan LA, et al. Microbial tannases: advances and perspectives. Appl Microbiol Biotechnol. 2007;76:47-59. DOI: 10.1007/s00253-007-1000-2.

[53] Angelova MB, Pashova SB, Spasova BK, Vassilev SV, Slokoska LS. Oxidative stress response of filamentous fungi induced by hydrogen peroxide and paraquat. Mycological Res. 2005;109(2):150-8. DOI: 10.1017/S0953756204001352.

[54] Oliveira M, Pereira C, Bessa C, Araujo R, Saraiva L. Hydrogen peroxide-induced secondary necrosis in conidia of Aspergillus fumigatus. Can J Microbiol. 2016;62:95-101. DOI: 10.1139/cjm-2015-0561.

[55] Wojdyła AT. The possibility of using the preparation Huwa-San TR-50 in the protection of ornamental plants against leaf pathogens. Progress in Plant Protection/Postępy w Ochronie Roślin. 2012;52(1):106-11. Available from: https://pdfs.semanticscholar.org/529a/7fdad9b585ae67d80a8e387198a113b48c30.pdf. 